ЛІЛІЯ МІДАК, кандидат хімічних наук, дочент, дочент кафедри хімії середовища та хімічної освіти, ДВНЗ "Прикарпатський національний університет імені Василя Стефаника", Україна ORCID: 0000-0002-3213-5968 lilia.midak@gmail.com

ЮРІЙ ПАХОМОВ, аспірант кафедри хімї середовищ а та хімічної освіти, ДВНЗ "Прикарпатський національний університет імені Василя Стефаника", Україна Jura.pahomov@gmail.com

ОЛЬГА КУЗИШИН, кандидат фізико-математичних наук, доиент кафедри хімії середовища та хімічної освіти, ДВНЗ "Прикарпатський національний університет імені Василя Стефаника", Украӥна ORCID ID 0000-0002-6737-6577 olgaifua3108@gmail.com

ЛІЛІЯ БАЗЮК, кандидат фізико-математичних наук, доиент кафедри хімії середовища та хімічної освіти, ДВНЗ "Прикарпатський національний університет імені Василя Стефаника", Украйна ORCID: 0000-0001-5690-8606 liliya30@ukr.net ХРИСТИНА БУЖДИГАН, аспірант кафедри хімії середовища та хімічної освіти, ДВНЗ "Прикарпатський начіональнии університет імені Василя Стефаника", Україна khrystja.buzhdyhan@gmail.com

\title{
ВИКОРИСТАННЯ ТЕХНОЛОГІЇ ДОПОВНЕНОЇ РЕАЛЬНОСТІ ПІД ЧАС ВИВЧЕННЯ ПРИРОДНИЧИХ ТЕМ У ПОЧАТКОВІЙ ШКОЛІ
}

LILIA MIDAK, Candidate of Chemical Sciences, Associate Professor at the Department of Environmental Chemistry and Chemistry Education, SHEE "Precarpathian National University named after Vasyl Stefanyk", Ukraine

YURII PAKHOMOV, student, SHEE "Precarpathian National University named after Vasyl Stefanyk", Ukraine OLHA KUZYSHYN, Candidate of Physical and Mathematical Sciences, Associate Professor at the Department of Environmental Chemistry and Chemical Education, SHEE "Precarpathian National University named after Vasyl Stefanyk", Ukraine

LILIA BAZIUK, Candidate of Physical and Mathematical Sciences, Associate Professor at the Department of Environmental Chemistry and Chemical Education, SHEE "Precarpathian National University named after Vasyl Stefanyk", Ukraine

KHRYSTYNA BUZHDYHAN, Postgraduate at the Department of Environmental Chemistry and Chemical Education, SHEE "Precarpathian National University named after Vasyl Stefanyk", Ukraine

\section{AUGMENTED REALITY: HOW CAN THIS TECHNOLOGY BE BENEFICIAL (USEFUL, HELPFUL) FOR STUDYING NATURAL SCIENCES IN PRIMARY SCHOOL}

У роботі створено мобільний додаток (на платформі Android) для візуалізації хімічної будови води та відтворення відеоматеріалів лабораторних дослідів, які можна використати вчителю та учням для ефективної підготовки до вивчення тем природничого циклу та проведення лабораторних дослідів в початковій школі з використанням лепбуку. Використання об'єктів доповненої реальності дає можливість вчителю швидко та доступно пояснити великий об'єм тео-

(C) Л. Мідак, Ю. Пахомов,

О. Кузишин, Л. Базюк, Х. Буждиган ретичного матеріалу з якісним демонстраційним матеріалом, а учням ефективно його засвоїти, розвиває у них творче мислення та підвищує мотивацію до навчання. Використання даної технології є особливо ефективним у поєднанні з лепбуком, оскільки сприяє розвитку творчості, уяви, може використовуватись одночасно групою дітей (в тому числі за участю дорослого як партнера), має дидактичні властивості.

Ключові слова: інформаційнокомунікативні технології, технологія Augmented Reality, мобільне навчання, 3D-візуалізація, лепбук.
Summary. A mobile application for video recording of practical works and laboratory experiments was created within the research. The pupils received an opportunity to get acquainted with safety regulations before work performance, as well as with the equipment and reagents, needed for the performance and with the work progress in video form. Images of parts of practical work or a laboratory experiment, based on the platform "Vuforia", implemented in software as objects of augmented reality, having used a multiplatform instrument for two and three dimensional "Unity 3D" 
apps, were chosen as "markers" of the mobile app.

Key words: information and communication technologies, Augmented Reality technology, mobile education, 3D-visualisation, a lap book.

Мета: створити мобільний додаток (на платформі Android) для візуалізації хімічної будови води та відтворення відеоматеріалів лабораторних дослідів, які можна використати вчителю та учням для ефективної підготовки до вивчення тем природничого циклу, проведення лабораторних дослідів у початковій школі з використанням лепбуку.

Постановка проблеми в загальному вигляді. Сьогодні розвиток інформаційно-комунікаційних технологій дає можливість модернізувати навчальний процес у початковій школі, використовуючи різноманітні тренди сучасної освіти. Нові методики викладання природничо-математичних дисциплін, і хімії зокрема, мають ураховувати сучасні вимоги до застосування інформаційних технологій (Кравець, Мідак \& Кузишин, 2017 , с. 151). Застосування інформаційно-комунікативних технологій (IКТ) у викладанні хімії дозволяє інтенсифікувати освітній процес, прискорити передачу знань і досвіду, а також підвищити якість навчання та освіти (Кравець, Мідак \& Кузишин, 2017 , с. 107). Використання на уроках мультимедійних презентацій, Інтернет-ресурсів дає можливість вчителю доступно пояснити теоретичний матеріал, підвищити інтерес учнів до навчання, краще утримати їх увагу.

Разом $з$ тим природничі науки $\epsilon$ переважно експериментальними. Ефективне засвоєння знань учнями з природознавства, а пізніше фізики, хімії, біології, географії та астрономії, залежить не тільки від способу подачі теоретичного матеріалу, але й від реалізації експериментальної частини у вигляді практичних робіт та лабораторних дослідів, яка потребує ретельної теоретичної підготовки, як для вчителя, так і для учнів.

Крім того, сьогоднішній стан матеріального забезпечення більшості шкіл вимагає покращення і не дає можливості для належного виконання практичних робіт та лабораторних дослідів учнями. У початковій школі проблемою стає ще і недостатня фахова підготовка вчителя початкових класів для проведення лабораторних дослідів з природознавства (фізики, хімії, біології тощо). Оскільки ці предмети не є фаховими для нього, то проведення такої експериментальної частини у класі вимагає додаткової підготовки.

У теперішній час система початкової освіти зазнасучтєвих змін (Пляцок \& Олійник, 2017, с. 9). Важливим аспектом освіти є формування у дитини вміння "вчитися самому". Сучасному учню необхідно не стільки багато знати, скільки послідовно й доказово мислити, проявляти розумову активність (Пляцуок \& Олійник, 2017, с. 9). Зміст і методи навчання у початковій школі спрямовані на розвиток уваги, пам'яті, творчої уяви, на вироблення вміння порівнювати, виділяти характерні властивості предметів, узагальнювати їх за певною ознакою, отримувати задоволення від знайденого рішення. Коли дитина сама діє 3 об'єктами, вона краще пізнає навколишній світ, тому пріоритет у роботі з учнями слід віддавати практичним методам навчання (Пляцуок \& Олійник, 2017, с. 9). Особливо ефективними такі методи будуть при вивченні інтегрованого курсу "Я досліджую світ". У зв'язку з цим перед педагогами стоїть завдання пошуку нових нестандартних форм взаємодії з вихованцями. На зміну традиційному приходить продуктивне навчання, яке спрямоване на розвиток творчих здібностей, формування в учнів інтересу до творчої діяльності. Одним з перспективних методів, які сприяють вирішенню даної проблеми, є лепбук (Пляичок \& Олійник, 2017, с. 9).

У поєднанні з технологією доповненої реальності лепбук дає можливість покращити усвідомлення теоретичного матеріалу, деталізувати та ілюструвати його, що сприятиме підвищенню пізнавальної діяльності та розвитку творчого мислення.

Аналіз досліджень і публікацій. На думку багатьох дослідників, технологія доповненої реальності (augmented reality, AR) є одним iз трендів сучасної освіти, який дозволяє модернізувати навчальний процес в умовах дигіталізації. Різноманітні аспекти впровадження технології AR у навчальний процес привертають увагу вітчизняних та закордонних дослідників (Н. Мартинова, Д. Самохвалов , В. Семашко, А. Вовк , С. Модло, Ю. Счкало, С. Семеріков , В. Ткачук, Т. Коделл , Д. Майзел , М. Рестіво, Д. Бреннан ). Будь-який засіб доповненої реальності може бути навчальним об'єктом (Модло, 2017, с. 94), якщо він $€$ керованим та сприяє взаємодії користувача 3 реальними об'єктами з метою вивчення їхніх властивостей у процесі експериментального дослідження.

Виклад основного матеріалу дослідження. На сучасну пору існує багато думок про те, що саме $\epsilon$ мобільним навчанням (Мідак, Пахомов та Луцишиин, 2017, с. 211). Свропейська гільдія з електронного навчання визначає його так (Virtual. . .): будь-яка діяльність, яка дозволяє людям бути більш продуктивними у споживанні, взаємодії або створенні інформації компактними цифровими пристроями, якщо людина призводить ці дії на регулярній основі, має надійний зв'язок і пристрій поміщається в кишені або сумочці. Таким чином, використовуючи сучасні мобільні пристрої (айфони, смартфони, планшети тощо), які є невід'ємними атрибутами сучасного учня загальноосвітньої школи, можна підготувати його до виконання практичної роботи 3 хімії, фізики чи біології, ознайомити з правилами безпеки та продемонструвати технікуії проведення (Мідак, 2019, c. 184).

Візуалізація навчального матеріалуполегшує його сприйняття та засвоєння. Правильно підібраний демонстраційний матеріал допомагає краще зрозуміти різноманітні процеси та явища, будову хімічних сполук, механізми їх взаємодій. Звичні 2Dзображення класичних підручників i посібників не дають повноцінного уявлення про ключові поняття природничих дисциплін: просторову будову молекул, фізичні процеси, механізми перебігу хімічних реакцій тощо. Таким чином, для ефективного вивчення природничих дисциплін, на сучасну пору доцільно використовувати численні демонстрації, які $\epsilon$ неможливими без використання програм-реалізаторів доповненої реальності.

Доповнена реальність (augmented reality, AR) дає можливість максимально візуалізувати об'єкт (атоми та молекули, їх взаємодії, схеми приладів, технологічних процесів тощо), тобто перевести 2D зображення у 3D, а також "оживити" його (Virtual...). За словами А. Вовк (http://www.bbc.com), завдяки тому, що AR дозволяє візуалізувати інформацію, показувати 3D-?моделі, учні мають змогу отримувати іï уже в го- 
товому для сприйняття вигляді і не будуть витрачати час і когнітивні зусилля на ії інтерпретацію.

Т. Коделл та Д. Майзел (Модло, 2017, c. 93), характеризуючи технологію доповненої реальності, вказують на простоту відображення в ній віртуальних об'єктів порівняно 3 віртуальною реальністю.

Будь-який засіб доповненої реальності може бути навчальним об'єктом (Модло, 2017, с. 94), якщо він $\epsilon$ керованим та сприяє взаємодії користувача 3 реальними об'єктами 3 метою вивчення їхніх властивостей у процесі експериментального дослідження.

Застосування засобів доповненої реальності (Модло, 2017, с. 93; Restivo, 2014, c. 69):

дозволяє підвищити реалістичність дослідження;

забезпечує емоційний та пізнавальний досвід, що сприяє залученню студентів до систематичного навчання;

надає коректні відомості про установку у процесі експериментування;

створює нові способи подання реальних об'єктів у процесі навчання.

Oсвітні AR-технології збагачують візуальне і контекстуальне навчання, покращуючи змістовність інформації настільки, що до $80 \%$ з неї утримується в короткочасній пам'яті порівняно 3 25\% при сприйнятті на слух (традиційні лекції) або читанні тексту (Мартинова, Самохвалов \& Семашко, 2017, с. 107).

Метою використання технологій доповненої реальності в початковій школі $є$ побудова навчальної діяльності на основі взаємодії дорослих 3 дітьми, орієнтованої на інтереси i можливості кожної дитини; розвиток допитливості, пізнавальної мотивації та навчальної активності; розвиток уяви, творчої ініціативи, у тому числі мовленнєвої; можливість вибору дітьми матеріалів, видів роботи, учасників спільної діяльності; створення умов для участі батьків у спільній навчальній діяльності.

Переваги застосування (Плячьок \& Олійник, 2017, с. 9):

1. Допомагає за власним бажанням організувати отриману інформацію з вивченої теми.

2. Сприяє кращому розумінню та запам'ятовуванню матеріалу.

3. Зручний спосіб повторення та узагальнення вивченого.
4. Учень вчиться самостійно аналізувати та робити висновки.

5. Лепбук можна створити на будь-яку тему.

6. Створення лепбука є одним 3 видів спільної діяльності дорослого і дітей. Він може бути ще й формою презентації підсумків проекту або тематичного тижня.

7. Дитина вчиться самостійно обирати та впорядковувати інформацію, яку вона додасть у лепбук.

8. Учень більш зацікавлений у навчанні, коли воно "оживає", до нього можна торкнутись.

9. Виготовляти лепбук можна індивідуально або групою, обираючи посильні завдання для кожної дитини.

10. Лепбук може бути змістовним елементом розвивального середовища групи.

Єдиний "недолік": для виготовлення лепбука потрібен час, фантазія, зусилля та відсутність ліні (Пляцчок \& Олійник, 2017, с. 9).

Дана розробка присвячена вивченню учнями теми "Вода" у 1 класі (тиждень 12) на уроках "Я досліджую світ". Згідно з програмовими вимогами вивчення даної теми охоплює такі запитання та завдання:

Дослідницькі/проблемні запитання:

Де "живе" вода? Як вона мандpye?

Навіщо пити воду? Навіщо вона потрібна людям і природі?

Якою буває вода?

Що станеться, якщо її не буде?

Як берегти воду?

Завдання дванадцятого тижня

1. Формувати уявлення про розподіл води на Землі.

2. Навчити досліджувати властивості води.

3. Формувати розуміння значення води для рослин, тварин, людини.

4. Виробляти навички економного використання води.

5. Ознайомити учнів 3 творами мистецтва про використання води.

6. Формувати здоров'язбережну компетентність.

7. Навчати висловлювати свою думку, уважно слухати співрозмовника, взаємодіяти з однокласниками.

8. Формувати вміння використовувати малюнки, схеми для ілюстрування арифметичних дій (додавання/ віднімання).

Наприкінці дванадцятого тижня учні знатимуть:

- назви водойм свого краю;

- властивості води (прозора, без запаху, приймає форму посудини, без смаку);

- як "мандрує" вода;

- як економно використовувати воду;

- як дбайливо ставитися до водних багатств;

умітимуть:

- пояснити значення води у природі та житті людини;

- досліджувати властивості води;

- розпізнавати за фотографіями водойми різних видів;

- описувати свої враження від почутого, побаченого;

- уважно слухати один одного під час спілкування;

- дотримуватися безпечних прийомів праці.

1. Для ефективного вивчення даної теми природничого циклу доцільно використати лепбук з доповненою реальністю. У лепбуку наведено інформацію (http:// cikavosti.com/tsikavi-fakti-pro-moryata-okeani/\#hcq=FY9uu6r) про:

будову молекули води;

ii агрегатні стани;

кількість води в організмі;

знаходження води у природі;

таємниці води;

цікаві факти про воду.

Для формування практичних навичок під час вивчення даної теми можна виконати такі експерименти:

1. Поверхневий натяг

1.1. Дослідження поверхневого натягу.

1.2. Руйнування поверхневого натягу.

2. Капілярний ефект

2.1. Дослідження капілярного ефекту.

2.2. Живлення рослин.

3. Методи очистки

3.1. Підбір оптимального фільтра.

3.2. Очистка води серветкою.

Метою роботи є створення мобільного додатка (на платформі Android) для візуалізації хімічної будови води та відтворення відеоматеріалів лабораторних дослідів, які можна використати вчителю та учням для ефективної підготовки до вивчення тем природничого циклу та проведення лабораторних дослідів у початковій школі. У розробленому лепбуку об'єкти, відтворювані за технологією AR, мають відповідну помітку D AR про що вміщена вказівка на зворот1 лепбука.

У результаті роботи для візуалізації навчального матеріалу розроблено безкоштовний мобільний дода- 
ток LiCo.STEM, який можна завантажити з загальнодоступного ресурсу Google Play Market.

На першому етапі було розроблено 3D-зображення молекули води та структури льоду (кристалічна гратка), води та водяної пари.

Доповнена реальність дає можливість максимально візуалізувати молекулу води, тобто перевести 2D зображення у 3D, а також "оживити" іii (Кравець, Мідак та Кузишин, 2017 , с. 151). Використання такого засобу ІКТ під час вивчення нового матеріалу дозволяє розвинути та покращити просторову уяву учнів, "побачити" невидиме (молекулу, кристалічну гратку) та глибше зрозуміти почутий навчальний матеріал, що сприятиме кращому його засвоєнню та формуванню певних практичних навичок (Кравецьь, Мідак та Кузишин, 2017, c. 151). Цей метод має переваги над застосуванням комп'ютерних програм, оскільки дає можливість за допомогою мобільного телефону чи планшету візуалізувати рисунки лепбуку в будь-якому місці знаходження учня (у класі, під час екскурсії на вулиці, удома тощо) та не вимагає перебування перед комп'ютером чи ноутбуком.

Для використання технології AR мітки доповненої реальності створено (Кравець, Мідак та Кузишин, 2017 , с. 151) на основі платформи "Vuforia"; 3D-об'єкти (молекула води та структури льоду, води та пари) змодельовані (Кравець, Мідак та Кузишин, 2017, c. 151) у програмі 3DMax, об'єкти доповненої реальності реалізовано за допомогою багатоплатформового інструмента для розробки дво- та тривимірних мобільних додатків "Unity 3D".

У разі наведення на маркер (рис. 1-4) мобільного телефону чи планшету із завантаженим мобільним додатком рисунок "оживає", на екрані з'являється його тривимірна модель, 3 якою можна проводити певні маніпуляції (обертання, збільшення, перегляд під різними кутами) для кращого усвідомлення її будови, принципу дії тощо.

На другому етапі було створено відеоматеріали лабораторних дослідів дослідження поверхневого натягу, капілярного ефекту та методів очистки води.

Розроблені відеоматеріали демонструють лабораторні досліди у виконанні досвідченого лаборанта $з$ дотриманням усіх правил техніки безпе-

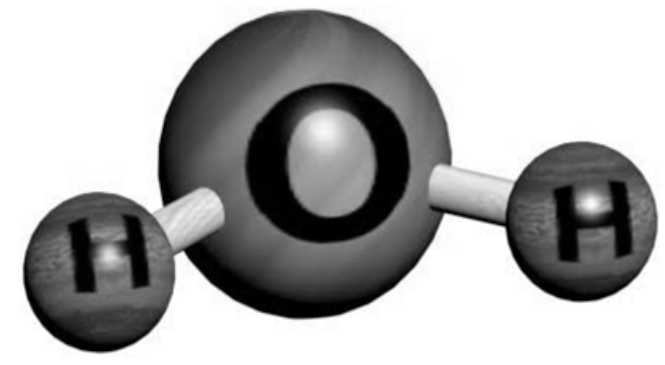

(1) $A R$ ?

Рис. 1. 2D-зображення молекули води, розміщене на лепбуку, яке відтворюється за технологієо AR мобільним додатком LiCo.STEM

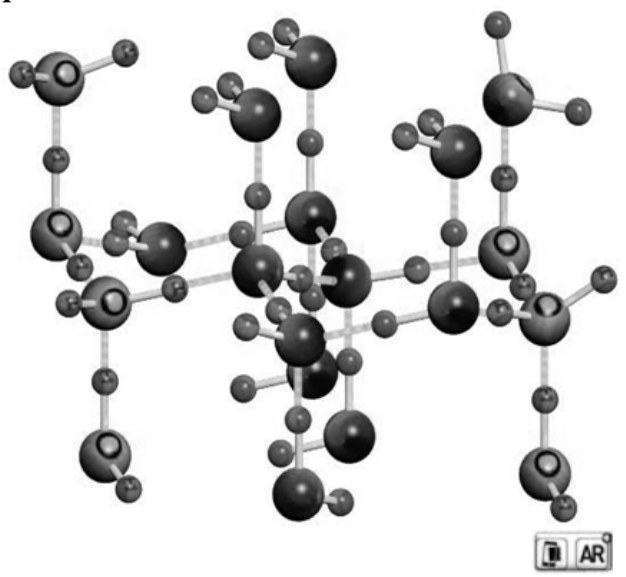

Рис. 2. 2D-зображення кристалічної гратки льоду, розміщене налепбуку, яке відтворюється за технологією AR мобільним додатком LiCo.STEM.

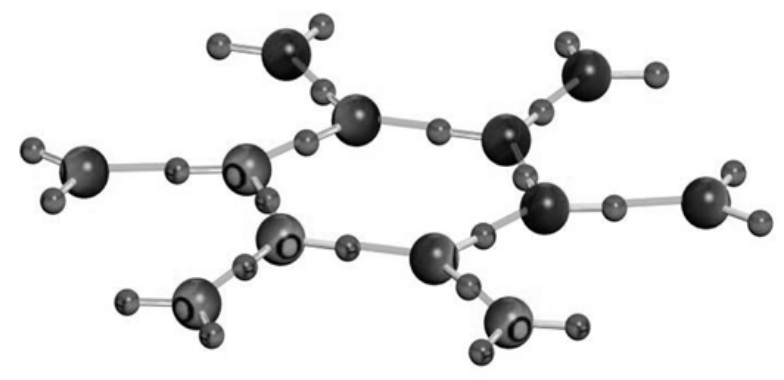

(1) AR

Рис. 3. 2D-зображення структури рідкої води, розміщене на лепбуку, яке відтворюється за технологією AR мобільним додатком LiCo.STEM.

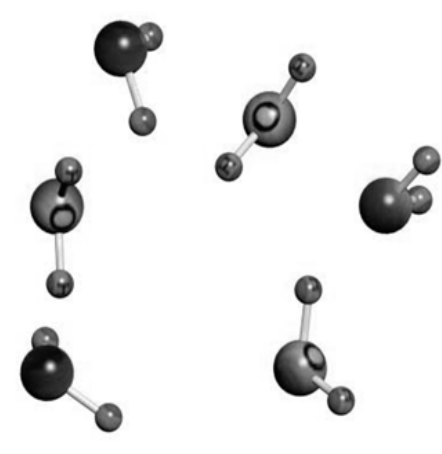

\section{(1) $A R$}

Рис. 4. 2D-зображення молекул водяної пари, розміщене на лепбуку, яке відтворюється за технологією AR мобільним додатком LiCo.STEM. 
ки. Проведення експерименту супроводжується текстовим поясненням. Використання розроблених відеоматеріалів дає можливість учню (під керівництвом учителя чи батьків) повторити такі досліди у класі або домашніх умовах, полегшує сприйняття даного матеріалу та демонструє іноді складну для розуміння експериментальну частину в доступній формі.

Відтворення розроблених відеоматеріалів на мобільних пристроях відбувається шляхом їх "прив'язування" до індивідуальних рисунків-"маркерів" для кожного лабораторного досліду (рис. 5-7).

Для "маркерів" були обрані векторні зображення, що передають зміст досліду, які програмно реалізовані як об'єкти доповненої реальності, за допомогою багатоплатформового інструмента для розробки дво- та тривимірних додатків "Unity 3D".

На рuc. 5-7 наведено приклади розроблених "маркерів" до рекомен- дованих лабораторних дослідів теми "Вода", розміщених на лепбуку, для учителів та учнів початкової школи.

Висновки та перспективи подальших досліджень. Розроблено мобільний додаток (на платформі Android) для візуалізації хімічної будови води та відтворення відеоматеріалів лабораторних дослідів, які можна застосувати вчителю та учням для ефективної підготовки до вивчення тем природничого циклу інтегрованого курсу "Я досліджую світ" та проведення лабораторних дослідів у початковій школі з використанням лепбуку. У поєднанні з технологією доповненої реальності лепбук дає можливість покращити усвідомлення теоретичного матеріалу, деталізувати та ілюструвати його, що сприятиме підвищенню пізнавальної діяльності та розвитку творчого мислення. Використання таких технологій дозволяє побудувати навчальну діяльність на основі взаємодії дорослих з дітьми, орієнтованої на інтере-

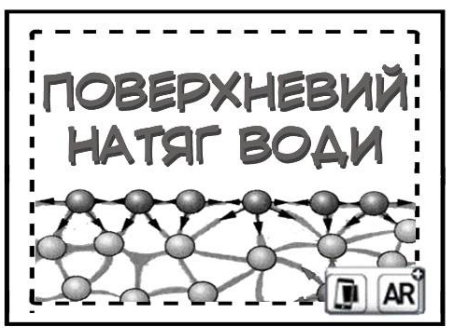

Рис. 5. «Маркер» для відтворення лабораторних дослідів для дослідження поверхневого натягу, розміщений на лепбуку (відтворюється за технологієо AR мобільним додатком LiCo.STEM)

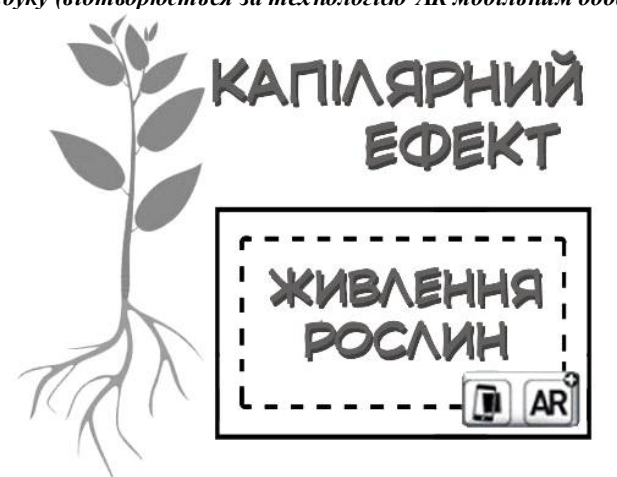

Рис. 6. «Маркер» для відтворення лабораторних дослідів для дослідження капілярного ефекту, розміщений налепбуку (відтворюється за технологіөо AR мобільним додатком LiCo.STEM)

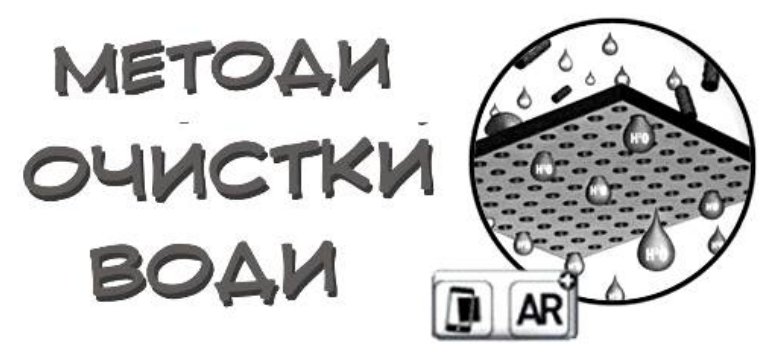

Рис. 7. «Маркер» для відтворення лабораторних дослідів для дослідження методів очистки води, розміщений на лепбуку (відтворюється за технологієо AR мобільним додатком LiCo.STEM)

си і можливості кожної дитини; розвиток допитливості, пізнавальної мотивації та навчальної активності; розвиток уяви, творчої ініціативи, у тому числі мовленнєвої; можливість вибору учнями матеріалів, видів роботи, учасників спільної діяльності; створення умов для участі батьків у спільній навчальній діяльності.

\section{СПИСОК ЛІТЕРАТУРИ}

Кравець, І. В., Мідак, Л. Я. \& Кузишин, О. В. (2017). Технологія Augmented Reality як засіб для покращення ефективності вивчення хімічних дисииплін. Тези доп. Всеукраїнської науково-практичної конференції з міжнародною участю "Сучасні інформаційні технології та інноваційні методики навчання: досвід, тенденції, перспективи". Тернопіль.

Мартинова, Н., Самохвалов, Д. \& Семашко В. (2017). Ефективні рішення організації процесу навчання: поєднання друкованих навчальних матеріалів 3 мобільними системами доповненої реальності. Технічні науки та технологї, 3 (9), 107-114. DOI: 10.25140/2411-5363-2017-3(9)-107-114

Мідак, Л. Я., Луцишин, В. М., Пахомов, Ю. Д. \& Кравець, І. В. (2018). Використання технологій мобільного навчання на уроках хімії в закладах загальної середньої освіти. Інформаційні технологї в освіті та науц̧і. Мелітополь : ФОП Однорог Т. В., 10, 184-187.

Мідак, Л. Я., Пахомов, Ю. Д. \& Луцишин, В. М. (2017). Технології мобільного навчання на практичних заняттях 3 хімії в загальноосвітній школі. Тези доп. Всеукраїнської науково-практичної конференції 3 міжнародною участю "Сучасні інформаційні технології та інноваційні методики навчання: досвід, тенденції, перспективи". Тернопіль, 211-214.

Модло, Є. О., Счкало, Ю. В., Семеріков, С. О. \& Ткачук, В. В. (2017). Використання технології доповненої реальності у мобільно орієнтованому середовищі навчання ВНЗ. Наукові записки, 11 (I), 93-100.

Пляцок, А. О. \& Олійник, В. В. (2017). Використання технології "лепбук в роботі з дошкільниками. Вінниця: КУ "ММК".

Restivo M. T., Chouzal F., Rodrigues J., Menezes P., Patrao B. \& Lopes J. B. (2014). Augmented Reality in Electrical Fundamentals. International Journal of Online 
Engineering (iJOE), 6, 68-72. URL : http://online-journals.org/index.php/ijoe/article/download/4030/3323

Virtual Reality Desktops for Vive, Rift, and Windows VR Compared. URL : https://roadtovr.com /virtual-realitydesktop-compared-oculus-rift-htcvive/.

URL : http://www.bbc.com

URL : http:/cikavosti.com/tsikavifakti-pro-morya-ta-okeani/ \#hcq $=$ FY9uu6r

\section{REFERENCES}

Kravets, I., Midak, L. \& Kuzyshyn (2017). Tekhnolohiia Augmented Reality yak zasib dlia pokrashchennia efektyvnosti vyvchennia khimichnykh dystsyplin. Proceedings of the AllUkrainian scientific-practical conference with international participation "Modern information technologies and innovative teaching methods: experience, trends, perspectives". Ternopil.

Martynova, N., Samokhvalov, D. \& Semashko, V. (2017). Efektyvni rishennia orhanizatsii protsesu navchannia: poiednannia drukovanykh navchalnykh materialiv z mobilnymy sys-temamy dopovnenoi realnosti. Tekhnichni nauky ta tekhnolohii, 3 (9), 107-114.

Midak, L. (2018). Vykorystannia tekhnolohii mobilnoho navchannia na urokakh khimii v zakladakh zahalnoi serednoi osvity. Information technology in education and science: Collection of scientific works, 10, 184 187.

Midak, L., Pakhomov, Ju. \& Lutsyshyn, V. (2017). Tekhnolohii mobilnoho navchannia na praktychnykh zaniattiakh z khimii $v$ zahalnoosvitnii shkoli. Proceedings of the All-Ukrainian scientific-practical conference with international participation "Modern information technologies and innovative teaching methods: experience, trends, perspectives", Ternopil, 9-10, 211-214.

Modlo, Ye., Yechkalo, Yu., Semerikov, S. \& Tkachuk, V. (2017). Vykorystannia tekhnolohii dopovnenoi realnosti u mobilno oriientovanomu seredovyshchi navchannia VNZ. Scientific notes, 11 (I), 93-100.
Pliatsok, A. \& Oliinyk, V. (2017). Vykorystannia tekhnolohii "lepbuk" v roboti z doshkilnykamy. Navchalnometodychnyi posibnyk. Vinnytsia : KU "MMK".

Restivo, M., Chouzal, F., Rodrigues, J., Menezes, P., Patrao, B. \& Lopes, J. (2014). Augmented Reality in Electrical Fundamentals. International Journal of Online Engineering (iJOE), 10 (6), 68-72. URL : http://online-journals.org/ index.php/i-joe/article/download/4030/ 3323.

Brennan, D. Virtual Reality Desktops for Vive, Rift, and Windows VR Compared. URL : https:// roadtovr.com/virtual-reality-desktopcompared-oculus-rift-htc-vive/, last accessed 2019/01/31.

URL: http://www.bbc.com

URL : http://cikavosti.com/tsikavifakti-pro-morya-ta-okeani/ \#hcq=FY9uu6r

Стаття надійшла 11.11.2019p. 